\title{
Penerapan Strategi Pembelajaran Problem Based Learning untuk Meningkatkan Kemampuan Pemecahahan Masalah Matematis Siswa Kelas IV SD
}

\section{Indhira Asih Vivi Yandhari', Trian Pamungkas Alamsyah², Dede Halimatusa'diah ${ }^{3}$}

\author{
1,2,3Universitas Sultan Ageng Tirtayasa
}

Corresponding Author: Email: indhira_1969@untirta.ac.id'

DOI: http://dx.doi.org/10.15294/kreano.v10i2.19671

Received: June 25 2019; Accepted: September 27 2019; Published: December 42019

\begin{abstract}
Abstrak
Penelitian ini dilatarbelakangi dengan rendahnya kemampuan pemecahan masalah matematis siswa serta strategi pembelajaran yang masih bertumpu pada guru. Salah satu alternatifnya yakni diterapkalah strategi pembelajaran Problem Based Learning, karena strategi ini diharapakan dapat meningkatkan kemampuan pemecahan masalah matematis siswa. Penelitian ini memiliki tujuan untuk mengetahui pencapaian akhir dan peningkatan kemampuan pemecahan masalah matematis siswa yang menggunakan strategi pembelajaran Problem Based Learning lebih baik dari pada siswa yang menggunakan strategi pembelajaran Inkuiri. Metode penelitian yang digunakan adalah quasi ekperiment dengan desain non-equivalent control group. Teknik sampel menggunakan teknik purposive sampling, dimana kelas IV-A sebagai kelas ekperimen dan kelas IV-B sebagai kelas kontrol. Hasil analisis data menunjukan ratarata skor posttest kelas ekperimen 75,03 dan kelas kontrol 68,7. Rata-rata data Gain kelas ekperimen 0,59 dan kelas kontrol 0,51. Hasil analisis tersebut memberikan kesimpulan bahwa pencapaian akhir dan peningkatan kemampuan pemecahan masalah matematis siswa kelas ekperimen lebih baik daripada kelas kontrol.
\end{abstract}

\begin{abstract}
The research is motivated by the low mathematical problem solving abilities of students and learning strategies that are still based on the teacher. One of the alternative is to apply the learning strategies of Problem Based Learning, because this strategy is expected to improve students' mathematical problem solving abilities. This study has a goal whether the final achievement and improvement of students' mathematical problem solving abilities using Problem Based Learning learning strategies is better than students who use Inquiry learning strategies. The research method used was a quasi experiment with a non-equivalent control group design. The sample technique used purposive sampling technique, where class IV-A as the experimental class and class IV-B as the control class. The results of data analysis showed an average posttest score of experimental class 75.03 and control class 68.7. The average Gain data of the experimental class is 0.59 and the control class is 0.51 . The results of the analysis provide the conclusion that the final achievement and improvement of experimental class mathematical problem solving abilities are better than the control class.
\end{abstract}

Keywords: mathematical problem solving skill; strategies of problem based learning 


\section{PENDAHULUAN}

Matematika merupakan salah satu mata pelajaran yang sangat penting dalam dunia pendidikan, karena pada kenyataanya pembelajaran matematika ini bersifat kontinyu artinya siswa akan memperoleh pembelajaran matematika dari pendidikan dasar sampai perguruan tinggi, sehingga matematika perlu diberikan pada semua siswa. Pembelajaran matematika juga bertujuan untuk membekali siswa dengan kemampuan berpikir logis, analistis, sistematis, kritis serta kemampuan bekerja sama. Pada kenyataanya dengan tujuan yang baik tersebut, tidak semua siswa menyukai matematika, sampai saat ini matematika masih dianggap sebagai mata pelajaran yang sulit dan tidak menyenangkan bagi siswa, bahkan sejumlah siswa menganggap matematika sebagai mata pelajaran yang menakutkan, dengan dasar pemikiran tersebut menyebabkan siswa mengalami kesulitan dalam memahami dan belajar matematika, hal ini akan berpengaruh pada rendahnya kemampuan yang dimiliki siswa dalam matematika, dan salah satunya adalah kemampuan pemecahan masalah matematis.

Kemampuan pemecahan masalah matematis perlu mendapatkan perhatian khusus dalam proses pembelajaran matematika dari jenjang pendidikan dasar, hal ini dikarenakan pemecahan masalah merupakan salah satu kemampuan yang harus dikuasai siswa setelah belajar matematika. Mulyono (2009) menyatakan bahwa kemampuan pemecahan masalah matematis penting dimiliki oleh setiap siswa dengan beberapa alasan, yaitu menjadikan siswa lebih kritis dan analitis dalam mengambil keputusan di dalam kehidupan. Oleh karena itu kemampuan ini sangat diperlukan siswa terkait dengan kebutuhan siswa untuk memecahkan masalah yang dihadapi dalam kehidupan sehari-hari termasuk dalam proses pembelajaran terkait menyelesaikan soal, meskipun demikian kemampuan siswa dalam menyelesaikan soal yang mengacu pada kemampuan pemecahan masalah masih rendah.

Berdasarkan kenyataan di lapangan hasil studi yang telah dilakukan oleh Jatisunda (2016) menyatakan bahwa salah satu faktor penyebabnya antara lain siswa di Indonesia pada umumnya kurang terlatih dalam menyelesaikan soal-soal dengan karakteristik seperti soal-soal pada TIMSS dan PISA. Karakteristik soal-soal tersebut, menuntut siswa untuk menggunakan penalaran, argumentasi dan kreativitas dalam menyelesaikannya yaitu soal-soal tes yang berbentuk pemecahan masalah. Selain itu hasil penelitian yang dilakukan Widodo dan Novianto (2017) mengemukakan bahwa rendahnya kemampuan pemecahan masalah dilihat dari hasil uji coba terbatas dengan jumlah 33 siswa diperoleh rata-rata 0,23 dimana rata-rata tersebut berada pada kategori yang rendah.

Berdasarkan kenyataan yang sudah dikemukakan di atas, juga ditemui oleh peneliti pada saat observasi awal yang dilakukan dikelas IV SD Negeri Serang 20. Peneliti memperoleh temuan-temuan mengenai sikap siswa selama proses pembelajaran dikelas, terutama pada saat pembelajaran matematika. Siswa terlihat kurang tertarik dengan materi yang dijelaskan oleh guru, hal ini dikarenakan guru kurang melibatkan siswa dalam proses pembelajaran sehingga siswa cenderung pasif dalam pembelajaran. Pada proses pembelajaran masih berpusat pada guru, karena strategi pembelajaran yang diterapkan guru selama ini belum maksimal dimana dalam hal ini guru masih menggunakan strategi atau metode pembelajaran yang kurang bervariatif, dengan demikian kemampuan pemecahan masalah matematis siswa kurang berkembang dengan baik dan siswa menjadi tidak aktif dalam proses pembelajaran, oleh karena itu diperlukan suatu strategi pembelajaran yang sesuai dengan permasalahan-permasalahan yang dihadapi siswa dalam proses pembelajaran di kelas sebagai upaya perbaikan terhadap permasalahan yang ada. Berdasarkan hal tersebut maka strategi pembelajaran Problem Based Learning dapat diterapkan sebagai alternatif pembelajaran di kelas.

Strategi pembelajaran Problem Based Learning menawarkan kebabasan siswa dalam proses pembelajaran. Rusmono (2014) mengatakan bahwa dalam strategi pembelajaran Problem Based Learning siswa diharapkan untuk terlibat dalam proses penelitian 
yang mengharuskannya mengidentifikasi permasalahan, mengumpulkan data, dan menggunakan data tersebut untuk pemecahan masalah, oleh karena itu dengan menggunakan strategi pembelajaran Problem Based Learning siswa akan dihadapkan pada masalah dalam proses pembelajaran, dengan demikian akan membuat siswa aktif karena merasa tertantang untuk bekerjasama dan mengasah kemampuan menyelesaikan masalah dengan cara mengumpulkan dan menganalisis data agar dapat memecahkan masalah serta menemukan solusinya, oleh karena itu strategi pembelajaran sangat mempengaruhi kegiatan proses pembelajaran sehingga guru sebaiknya menggunakan strategi pembelajaran yang efektif untuk mencapai tujuan pembelajaran.

\section{METODE}

Penelitian ini adalah penelitian eksperimen dengan jenis penelitiannya adalah quasi eksperiment (eksperimen semu). Sugiyono (2015), mengemukakan bahwa kuasi eksperimen digunakan karena kelompok kontrol tidak dapat berfungsi sepenuhnya untuk mengontrol variabel-variabel luar yang mempengaruhi pelaksanaan eksperimen. Desain dalam penelitian yang digunakan adalah nonequivalent control group design, yaitu menggunakan kelompok yang sudah ada, Sugiyono (2015: 97), sebelum dua kelompok diberikan perlakuan, masing-masing kelompok diberikan tes awal (Pretest), kemudian diberikan perlakuan (Treatment) untuk kelas eksperimen dan kelas kontrol, setelah itu diberikan tes akhir (Posttest) pada kedua kelompok tersebut, dalam desain ini terdapat dua kelompok yaitu kelompok eksperimen dan kelompok kontrol (Sugiyono, 2015).

Populasi adalah keseluruhan subjek penelitian, Arikunto (2013). Populasi umumnya adalah seluruh siswa SD Negeri Serang 20 Semester Genap Tahun Ajaran 2019, sedangkan populasi target adalah seluruh siswa kelas IV SD Negeri Serang 20. Sampel Penelitian ini terdiri dari dua kelas, yaitu satu kelas sebagai kelas ekperimen dan satu kelas sebagai kelas kontrol. Penentuan sampel sasaran dalam penelitian ini adalah seluruh siswa kelas IV semester genap tahun ajaran 2019 di SD Negeri Serang 20, adapun teknik pengambilan sampel menggunakan teknik purposive sampling. Sugiono (2015) mengemukakan bahwa, Purposive sampling adalah teknik penentuan sampel dengan pertimbangan tertentu. Aspek perkembangan kognitif siswa dan materi yang akan disampaikan kepada siswa serta kelas yang digunakan dalam penelitian, peneliti mengambil sampel atas pertimbangan saran dari guru kelas IV, adapun kelas yang akan diteliti yaitu kelas IVA dan IVB untuk penentuan kelas eksperimen dan kelas kontrolnya sehingga hasilnya kelas IVA sebagai kelas eksperimen dan kelas IVB sebagai kelas kontrol.

Instrumen Penelitian yang digunakan dalam penelitian ini adalah instrument tes dan nontes. Instrumen tes digunakan untuk memperoleh data kuantitatif kemampuan pemecahan masalah matematis siswa, adapun indikator pemecahan masalah matematis yang digunakann menurut Soemarmo (Amam, 2017) adalah sebagai berikut: (1) Mengidentifikasi unsur yang diketahui, ditanyakan, dan kecukupan unsur yang diperlukan; (2) Menerapkan strategi untuk menyelesaikan masalah; (3) Menjelaskan atau menginterpretasi hasil penyelesaian masalah.

Instrumen tes yang digunakan dalam penelitian ini berupa soal uraian yang terdiri dari 6 butir soal. Soal tes dipergunakan dua kali, yaitu pada saat tes awal (Pretest) dan akhir pembelajaran (posttest) pada kedua kelompok sampel, yang terlebih dahulu diperiksa kepada para ahli yaitu dosen dan guru kelas IV SD Negeri Serang 20, setelah itu diuji coba untuk mengetahui tingkat kelayakan soal dengan diuji validitas, reliabilitas, daya pembeda, dan tingkat kesukarannya.

Penelitian ini juga menggunakan instrumen penelitian non tes, adapun instrumen non tes yang digunakan pada penelitian ini berupa observasi dan dokumentasi. Observasi dilakukan untuk mengetahui dan mengamati aktivitas siswa secara keseluruhan selama proses pembelajaran berlangsung yang digunakan untuk mengetahui permasalahan yang diteliti, sedangkan dokumentasi dalam penelitian ini berupa daftar nilai siswa, dan foto-foto kegiatan penelitian yang digunakan sebagai bukti nyata bahwa peneliti sudah me- 
lakukan kegiatan penelitian di lapangan.

Data hasil pretest dan posttest diolah dan dianalsis sesuai dengan rumusan masalah yang telah dibuat dengan menggunakan statistik deskriptif dan statistik inferensial. Statistik deskriptif digunakan untuk menganalisis data dengan cara mendeskripsikan atau menggambarkan data yang telah terkumpul. Statistik deskriptif berupa rata-rata, skor minumum, skor maksimum, simpangan baku dan varians sedangkan statistik inferensial digunakan untuk menganalisis data dengan membuat generalisasi pada data sampel agar hasilnya dapat diberlakukan pada populasi. Statistik Inferensial terbagi menjadi statistik parametric dan non parameterik. Statistik parametrik digunakan untuk menguji normalitas dan homogenitas suatu data. Sedangkan statistik non paramterik digunakan jika salah satu data atau kedua nya tidak normal maupun homogen. Hasil akhir analisis penelitian ini akan menjawab rumusan masalah dan hipotesis penelitian.

\section{HASIL DAN PEMBAHASAN}

Untuk menguji penelitian ini terdapat beberapa instrumen yang akan diberikan yakni pretest dan posttest, selanjutnya nilainilai dari pretest dan posttest tersebut diolah menggunakan analisis deskriptif dan analisis inferensial. Langkah awal yang dilakukan terhadap kedua kelas sampel yaitu dengan pemberian soal pretest yang bertujuan untuk mengetahui kemampuan awal pemecahan masalah matematis siswa setara atau tidak.

Berdasarkan Tabel 1 terlihat bahwa rata-rata hasil Pretest kelas eksperimen dan kelas kontrol tidak berbeda jauh. Hal ini memberi arti bahwa kemampuan awal pemecahan masalah matematis kedua kelas tidak terdapat perbedaan signifikan. Setelah dilakukan pretest kelas eksperimen diberi perlakukan dengan strategi pembelajaran Problem Based Leraning dan kelas kontrol dengan startegi pembelajaran Inkuiri. Kemudian siswa melakukan posttest untuk mengetahui kemampuan pemecahan masalah matematis siswa setelah pemberian perlakuan.

Berdasarkan Tabel 2 terlihat bahwa secara statistika deskriptif rata-rata siswa kelas eksperimen lebih tinggi dibandingkan dengan rata-rata siswa kelas kontrol. Oleh karena itu rata-rata hasil Posttest kelas eksperimen lebih baik dari pada kelas kontrol.

Berdasarkan nilai posttest tersebut, maka dapat diklasifikasikan tingkat kemampuan pemecahan masalah matematis siswa. Tingkat klasifikasi tersebut yakni, sangar tinggi (st), tinggi (t), cukup (c), rendah ( $r$ ) dan sangat rendah (sr), adapun klasifikasi kemampuan pemecahan masalah matematis siswa disajikan dalam Gambar 1.

Tabel 1. Statistik Deskriptif Data Pretest

\begin{tabular}{ccccccc}
\hline Pretest & Jumlah data & Min & Maks & Rata-Rata & Std Deviasi & Varians \\
\hline Kelas Ekperimen & 26 & 25 & 54 & 37,19 & 8,65 & 74,96 \\
Kelas Kontrol & 25 & 20 & 54 & 34,74 & 9,87 & 97,44 \\
\hline
\end{tabular}

Tabel 2.Statistik Deskriptif Data Posttest

\begin{tabular}{ccccccc}
\hline Posttest & Jumlah data & Min & Maks & Rata-rata & Std Deviasi & Varians \\
\hline Kelas Ekperimen & 26 & 50 & 96 & 75,03 & 12,95 & 167,5 \\
Kelas Kontrol & 25 & 46 & 92 & 68,7 & 13,26 & 176 \\
\hline
\end{tabular}

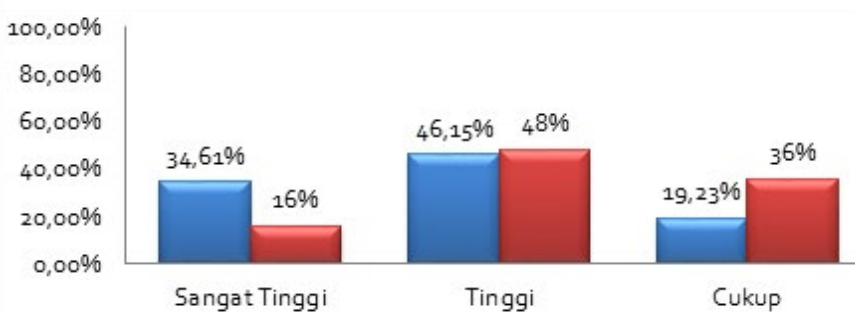

Gambar 1. Klasifikasi Tingkat Kemampuan Pemecahan Masalah Matematis 
Gambar 1 menunjukkan persentase nilai rata-rata kemampuan pemecahan masalah matematis siswa. Adanya peningkatan dikarena siswa mulai memahami langkah-langkah mengerjakan soal pemecahan masalah matematis. Tinggi rendahnya rata-rata peningkatan skor pretest dan posttest dilihat berdasarkan kriteria nilai $\mathrm{N}$-gain nya, ada yang rendah, sedang dan tinggi.

Berdasarkan Tabel 3 terlihat bahwa peningkatan rata-rata skor pretest dan posttest kelas ekperimen peningkatannya lebih tinggi dibandingkan kelas kontrol.

Data statistik deskripstif yang telah dijabarkan pada sebelumnya mungkin belum bisa menerangkan secara lengkap apakah kemampuan pemecahan masalah matematis siswa kelas eksperimen dan kelas kontrol berbeda atau sama pada hasil pretest, posttest dan $\mathrm{N}$-gain oleh karena itu data dari hasil tersebut diuji dengan statistik inferensial. Statistik inferensial pretest dapat dilihat pada Tabel 4 .

Berdasarkan Tabel 4 data kedua kelas berdistribusi normal. Adapun Data uji Homo- genitas Pretest yang ditunjukkan pada Tabel 4 berasal dari populasi yang homogen.

Berdasarkan hasil Tabel 5 didapat bahwa kedua data berdistribusi normal dan homogen dan $t_{\text {hitung }} t_{\text {tabel }}$ atau $1,711,67$ artinya $\mathrm{H}_{\mathrm{O}}$ ditolak, sehingga pencapaian akhir kemapuan pemecahan masalah matematis siswa yang menggunakan strategi pembelajaran Problem Based Learning lebih baik daripada siswa yang menggunakan strategi pembelajaran Inkuiri.

Berdasarkan hasil Tabel 6 didapat bahwa kedua data berdistribusi norml dan homogen dan $t_{\text {hitung }} t_{\text {tabel }}$ atau 2,00 1,67 artinya $\mathrm{H}_{\mathrm{O}}$ ditolak, sehingga peningkatan kemapuan pemecahan masalah matematis siswa yang menggunakan strategi pembelajaran Problem Based Learning lebih baik daripada siswa yang menggunakan strategi pembelajaran Inkuiri.

Salah satu kemampuan yang harus dimiliki siswa adalah kemampuan pemecahan masalah matematis. Utami dan Wutsqa (2017) mengungkapkan bahwa kemampuan pemecahan masalah menjadi salah satu tujuan pembelajaran matematika yang harus dicapai oleh siswa, karena dalam kehidupan sehari-

Tabel 3. Statistik Deskriptif Data Gain

\begin{tabular}{ccccccc}
\hline Kelas & Jumlah data & Min & Maks & Rata-rata & Std Deviasi & Varians \\
\hline Ekperimen & 26 & 0,33 & 0,92 & 0,59 & 0,17 & 0,0303 \\
Kontrol & 25 & 0,26 & 0,81 & 0,51 & 0,16 & 0,0280 \\
\hline
\end{tabular}

Tabel 4. Ringkasan Uji Statistik Skor Pretest Kemampuan Pemecahan Masalah Matematis Siswa

\begin{tabular}{ccccc}
\hline \multirow{2}{*}{ Kelas } & \multicolumn{2}{c}{ Uji Normalitas $\left(U j i-\chi^{2}\right)$} & \multicolumn{2}{c}{ Uji Homogenitas $(U j i-F)$} \\
\cline { 2 - 5 } & $\mathrm{T}_{\text {hitung }}<\mathrm{T}_{\text {tabel }}$ & Ket : & $\mathrm{F}_{\text {hitung }}<\mathrm{F}_{\text {tabel }}$ & $\mathrm{T}_{\text {hitung }}<\mathrm{T}_{\text {tabel }}$ \\
\hline Ekperimen & $6,9338<11,070$ & $\mathrm{H}_{\mathrm{O}}$ ditolak & \multirow{2}{*}{$1,20<1,97$} & \multirow{2}{*}{$\mathrm{H}_{\mathrm{O}}$ ditolak } \\
Kontrol & $5,252<11,070$ & $\mathrm{H}_{0}$ ditolak & & \\
\hline
\end{tabular}

Tabel 5. Ringkasan Uji Statistik Skor Posttetst Kemampuan Pemecahan Masalah Matematis Siswa

\begin{tabular}{|c|c|c|c|c|c|c|}
\hline \multirow{2}{*}{ Kelas } & \multicolumn{2}{|c|}{ Uji Normalitas (Uji - $\left.\chi^{2}\right)$} & \multicolumn{2}{|c|}{ Uji Homogenitas (Uji -F) } & \multicolumn{2}{|c|}{ Uji Hipotesis 1 (Uji-t) } \\
\hline & $\mathrm{T}_{\text {hitung }}<\mathrm{T}_{\text {tabel }}$ & Ket : & $\mathrm{F}_{\text {hitung }}<\mathrm{F}_{\text {tabel }}$ & Ket : & $T_{\text {hitung }}>T_{\text {tabel }}$ & Ket \\
\hline $\begin{array}{l}\text { ksperimen } \\
\text { Kontrol }\end{array}$ & $\begin{array}{l}2,7153<11,070 \\
3,7958<11,070\end{array}$ & $\begin{array}{l}\mathrm{H}_{\mathrm{O}} \text { ditolak } \\
\mathrm{H}_{0} \text { ditolak }\end{array}$ & $1,04<1,97$ & $\mathrm{H}_{\mathrm{O}}$ ditolak & $1,71>1,67$ & $\mathrm{H}_{\mathrm{O}}$ ditolak \\
\hline
\end{tabular}

Tabel 6. Ringkasan Uji Statistik Skor Gain Kemampuan Pemecahan Masalah Matematis Siswa

\begin{tabular}{ccccccc}
\hline \multirow{2}{*}{ Kelas } & \multicolumn{2}{c}{ Uji Normalitas $\left(U j i-\chi^{2}\right)$} & \multicolumn{2}{l}{ Uji Homogenitas $(U j i-F)$} & \multicolumn{2}{c}{ Uji Hipotesis 2 (Uji-t) } \\
\cline { 2 - 6 } & $\mathrm{T}_{\text {hitung }}<\mathrm{T}_{\text {tabel }}$ & Ket : & $\mathrm{F}_{\text {hitung }}<\mathrm{F}_{\text {tabel }}$ & Ket : & $\mathrm{T}_{\text {hitung }}>\mathrm{T}_{\text {tabel }}$ & Ket \\
\hline Eksperimen & $6,9308<11,070$ & $\mathrm{H}_{\mathrm{O}}$ ditolak & & \\
Kontrol & $6,7288<11,070$ & $\mathrm{H}_{0}$ ditolak & $1,08<1,97$ & $\mathrm{H}_{\mathrm{O}}$ ditolak & $2,00>1,67$ & $\mathrm{H}_{\mathrm{O}}$ ditolak \\
\hline
\end{tabular}


hari secara sadar maupun tidak sadar, setiap siswa dihadapkan dengan berbagai permasalahan yang menuntut kemampuan pemecahan masalah terkait dalam menyelesaikan soal.

Dimana hal tersebut dapat diterapkan dengan strategi pembelajaran Problem Based Learning, karena strategi ini berorientasi pada masalah kehidupan sehari-hari. Hal tersebut sesuai dengan pendapat Tyas (2017) yang mengungkapkan bahwa pembelajaran berbasis masalah termasuk kategori Teaching Via Problem Solving, dimana pembelajaran konten matematika dilakukan melalui penyajian masalah yang berorientasi inkuiri. Masalah yang disajikan dalam Problem Based Learning merupakan masalah dalam kehidupan sehari-hari dan melalui masalah tersebut mampu merangsang siswa mempelajari masalah ini berdasarkan pengetahuan dan pengalaman yang telah dimiliki oleh siswa sehingga dari pengalaman yang telah dimiliki siswa akan terbentuk pengetahuan dan pengalaman yang baru. Oleh karena itu penerapan Problem Based Learning dalam pembelajaran matematika dapat memfasilitas siswa dalam mengungkapkan permasalahan dan cara yang dimiliki siswa untuk menyelesaikan permasalahan tersebut kedalam model atau konteks matematika, sebagaimana pendapat Trianto (2007) bahwa pembelajaran berbasis masalah merupakan metode yang efektif untuk membantu siswa dalam memperoses informasi yang sudah ada dalam benaknya dan menyusun pengetahuan sendiri tentang dunia sosial dan sekitarnya. Sedangkan pembelajaran menggunakan strategi inkuiri mengarahkan pada suatu penemuan konsep matematika dengan cara mencari dan menemukan sendiri jawaban dari suatu permasalahan, Sanjaya (2006).

Setelah diterapkan strategi problem based learning untuk kelas ekperimen dan startegi pembelajaran inkuiri untuk kelas kontrol selama empat kali pertemuan, terdapat peningkatan nilai rata-rata kemampuan pemecahan masalah matematis siswa. Hal tersebut dapat dilihat dari hasil akhir yang diperoleh siswa, dimana nilai rata-rata siswa sebelum diberikan perlakuan memiliki ratarata 37,19 untuk kelas ekperimen sedangkan untuk kelas kontrol memiliki rata-rata 34, 74. Nilai rata-rata dari kedua kelompok tersebut berada pada kategori yang rendah. Sedangkan setalah diberikan perlukan, nilai rata-rata kedua kelas mengalami peningkatan dimana kelas ekperimen memiliki rata-rata 75,03 sedangkan untuk kelas kontrol memiliki ratarata 68,7 , nilai rata-rata tersebut berada pada kategori sedang. Walaupun hasil akhir samasama mengalami peningkatan, akan tetapi berdasarkan hasil uji-t satu pihak didapat bahwa $t_{\text {hitung }} t_{\text {tabel }}$ atau 1,71 1,67 artinya $\mathrm{H}_{\circ}$ ditolak, sehingga pencapaian akhir kemampuan pemecahan masalah matematis siswa kelas ekperimen lebih baik daripada siswa kelas kontrol.

Strategi pembelajaran Problem Based learning dan strategi inkuiri mampu meningkatkan kemampuan pemecahan masalah matematika siswa, sebagaimana Dwiyanto (2016) mengatakan bahwa Problem Based Learning merupakan strategi belajar yang menggunakan masalah sebagai langkah awal dalam mengumpulkan dan mengintegrasikan pengetahuan baru. Strategi ini juga berfokus pada keaktifan siswa dalam kegiatan pembelajaran. Siswa tidak lagi diberikan materi belajar secara satu arah seperti pada strategi pembelajaran konvensional, dengan strategi Problem Based Learning diharapkan siswa dapat mengembangkan pengetahuan mereka secara mandiri, adapun karakter pembelajaran berbasis masalah ini adalah 1) pelajaran berfokus pada pemecahan masalah, 2) tanggung jawab untuk memecahkan masalah bertumpu pada siswa, 3) guru mendukung proses saat siswa mengerjakan masalah.

Proses pemecahan masalah juga dapat pula dikembangkan melalui strategi inkuiri, hal ini sesuai dengan pendapat Hendracipta (2017) strategi inkuiri adalah rangkaian kegiatan yang menekan pada proses berfikir secara kritis dan analitis untuk mencari dan menemukan sendiri jawaban dari suatu masalah. Melalui pembelajarn ini siswa mampu membangun rasa ingin tahu dan meningkatkan kepercayaan dirinya. Pada penerapan strategi pembelajaran inkuiri siswa diberikan kebebasan berpendapat dalam sebuah kelompok diskusi untuk membiasakan siswa berinteraksi dengan siswa yang lain dalam memecahkan 
suatu permasalahan yang sedang dihadapi.

Berdasarkan uraian diatas, bahwa dengan diterapkannya starategi problem based leraning untuk kelas ekperimen dan strategi pembelajaran inkuiri untuk kelas kontrol dapat meningkatkan kemampuan siswa dalam memecahkan masalah matematis, karena ada peningkatan kualitas bagi siswa. kualitas siswa yang meningkatkan yaitu kemampuan pemecahan masalah matematis dalam pembelajaran matematika. Setelah diterapkan strategi pembelajaran kepada masing-masing kelas, terdapat peningkatan nilai-nilai kemampuan pemecahan masalah matematis siswa. Dimana, untuk kategori sangat tinggi mencapai $34,61 \%$ pada kelas ekperimen dan 16\% pada kelas kontrol. Selanjutnya kategori tinggi di kelas ekperimen mencapai 46,15\% dan di kelas kontrol mencapai 48\%. Sedangkan untuk kategori cukup, pada kelas ekperimen $19,23 \%$ dan dikelas kontrol mencapai 36\%. Walaupun hasil akhir sama-sama mengalami peningkatan, akan tetapi berdasarkan hasil uji-t satu pihak didapat bahwa $t_{\text {hitung }} t_{\text {tabel }}$ atau 2,00 1,67 artinya $\mathrm{H}_{0}$ ditolak, sehingga peningkatan kemampuan pemecahan masalah matematis siswa kelas ekperimen lebih baik daripada siswa kelas kontrol.

\section{PENUTUP}

\section{Simpulan}

Berdasarkan penelitian yang dilakukan, diperoleh bahwa pencapaian akhir dan peningkatan kemampuan pemecahan masalah matematis siswa yang menggunakan strategi pembelajaran Problem Based Learning lebih baik daripada siswa yang menggunakan strategi pembelajaran inkuiri.

\section{DAFTAR PUSTAKA}

Amam, A. (2017). Penilaian Kemampuan Pemecahan Masalah Matematis Siswa SMP. Jurnal Teori Riset Matematika (Teorema), 2(1), 39-48

Arikunto, S. (2013). Prosedur Penelitian, Jakarta: PT. Rineka Cipta.

Dwiyanto, D. (2016). Strategi Pembelajaran Berbasis Masalah. Surabaya: CV. Garuda Mas Sejahtera (online di nulisbuku.com)

Jatisunda, M. G. (2016). Peningkatan Kemampuan Pemecahan Masalah Matematis Siswa SMP Melalui Pembelajaran dengan Pendekatan Kontekstual. Jurnal THEOREMS (The Original Research of Mathematics), 1(1).

Hendracipta, N., Syachruroji, A., \& Hermawilda, H. (2017). Perbedaan Hasil Belajar Siswa Antara yang Menggunakan Srategi Inkuiri dengan Strategi Ekspositori. Jurnal Pendidikan Sekolah Dasar (JPSD), 3(1), 33-41.

Mulyono, A. (2009). Pendidikan Bagi Anak Berkesulitan Belajar. Jakarta: Rineka Cipta.

Tyas, R. (2017). Kesulitan Penerapan Problem Based Learning Dalam Pembelajaran Matematika. Jurnal Tecnoscienza. 2(1), 44-52

Rusmono. (2014). Strategi Pembelajaran dengan Problem Based Learning Itu Perlu: Untuk Meningkatkan Profesionalitas Guru Jilid 2. Bogor: Penerbit Ghalia Indonesia.

Sanjaya, W. (2006). Strategi Pembelajaran Berorientasi Standard dan Proses Pendidikan, Jakarta: Kencana Prenada Media Group.

Sugiyono. (2014). Metodologi Penelitian Kualitatif kuantitatif \& RND Bandung: Alfabeta

Trianto. (2007). Model Pembelajaran Inovatif Berorientasi Konstruktivitik. Jakarta: Prestasi Pustaka.

Utami, R. W., \& Wutsqa, D. U. (2017). Analisis Kemampuan Pemecahan Masalah Matematika dan SelfEfficacy Siswa SMP Negeri di Kabupaten Ciamis. Jurnal Riset Pendidikan Matematika, 4(2), 166175.

Widodo, S., \& Kartikasari, K. (2017). Pembelajaran Pemecahan Masalah Matematis Siswa Sekolah Dasar dengan Model Creative Problem Solving (CPS). PRISMA, 6(1), 57-63. 